\title{
ИССЛЕДОВАНИЕ СОЛЮБИЛИЗАЦИИ ТЕТРА(ТРЕТ- БУТИЛ)ФТАЛОЦИАНИНА АЛЮМИНИЯ В МИЦЕЛЛАХ CREMOPHOR EL: НОВАЯ ФОРМА ПРЕПАРАТА ДЛЯ ФДТ
}

\author{
М.С. Белоусов ${ }^{1}$, М.А. Градова², Т.В. Дубинина' \\ ${ }^{1}$ Химический факультет, Московский государственный университет \\ им. М.В.Ломоносова, 119234, Россия, г. Москва, Ленинские горы, д. 1, с. 3. \\ ${ }^{2}$ Федеральный исследовательский центр химической физики им. Н.Н.Семенова РАН, \\ 119991, Россия, г. Москва, ул. Косыгина, д. 4.
}

DOI: 10.19163/MedChemRussia2021-2021-394

E-mail:mikbelousov99@gmail.com

Фотодинамическая терапия (ФДТ) представляет собой малоинвазивный метод лечения злокачественных новообразований с использованием фотосенсибилизатора (ФС).

Объектом настоящего исследования являлся ФС - тетра(mpem-бутил) фталоцианин алюминия 1. Гидрофобные трет-бутильные группы увеличивают мембранотропность 1. Однако одновременно возрастает склонность к агрегации в водных растворах. Одним из способов предотвращения агрегации гидрофобных лекарственных средств является их солюбилизация в мицеллах ПАВ. Проведено скрининговое исследование солюбилизации третбутилзамещенного фталоцианина алюминия 1 с использованием различных ионогенных и неионогенных ПАВ.

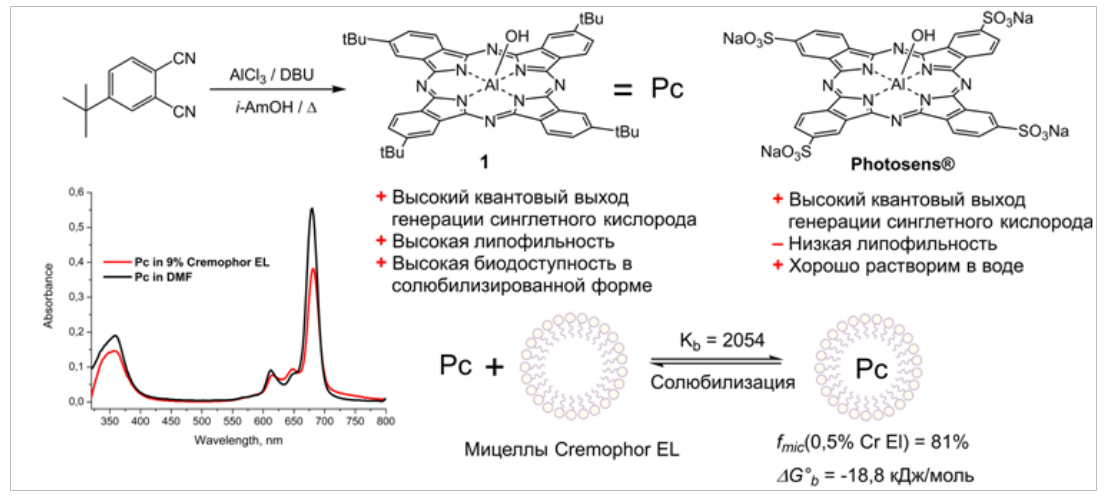

Наибольшую эффективность показал биосовместимый неионогенный ПAB Cremophor EL ${ }^{\circledR}$. В области концентраций ПАВ 0,05-1\% определены константа связывания ФС с мицеллами ( $\mathrm{K}_{\mathrm{b}}=2054$ л/моль), изменение энергии Гиббса связывания ( $\Delta \mathrm{G}^{\circ}{ }_{\mathrm{b}}=-18,8$ кДж/моль), а также рассчитан коэффициент солюбилизации $\mathrm{f}_{\text {mic }}(0,5 \% \mathrm{Cr} \mathrm{El})=81 \%$. 